\title{
Religious Pluralism, yet a Homogenous Stance on Interest Rate: The Case of Judaism, Christianity, and Islam
}

\author{
Ahmed S. Abou-Zaid' ${ }^{1}$, Tesa Leonce ${ }^{2}$
}

\begin{abstract}
Despite the conventional consensus that interest rates are efficient mechanism of allocating loanable funds and the most influential monetary policy instrument in modern economies, the three major monotheistic religions, Judaism, Christianity, and Islam, prohibit the use of interest and consider charging interest as an act of exploitation and extortion. Several passages and verses in the Torah, the Bible, and the Quran make their position on interest clear and definitive, from the Bible's dictum, "Do not charge your brother interest" to the Quran's exhortation "give up what remains of your demand for usury." This paper reviews those passages and verses, provides different scholars' perspectives on these verses, and relates them to the current financial system. The paper also presents several recent events that support the religious position by showing the negative impact of interest on countries, societies, and individuals. These events have, in fact, inspired many economists and financial institutions to seek alternatives to the current system.
\end{abstract}

KEY WORDS: $\quad$ Interest rates; relegions; Islam; Christianity; Judaism

JEL Classification: $\quad$ E4; Z1

'Eastern Illinois University - Economics, United States, 2Columbus State University - Economics, United States,

\section{Introduction}

In the modern economy, interest is known to be the price of money and is determined by the market forces of supply and demand. Interest serves many functions. It determines the propensity of people to consume or save and the feasibility of different investment opportunities. Interest has also become the major monetary policy instrument in almost every country in the world. In fact, it has been completely institutionalized

$\square$

Correspondence concerning this article should be addressed to: Ahmed S. Abou-Zaid Eastern Illinois University - Economics 600 Lincoln Ave. Coleman Hall 2375 Charleston, Illinois 61920 United States. E-mail: asabouzaid@eiu.edu in modern economies and accepted as the most efficient mechanism for allocating loanable funds and a vital tool for stabilizing the economy. Due to excessive interest charges by several financial intuitions, however, interest continues to be a concern in many modern societies. Different laws abolishing usury have been passed in various countries, such as the United States; however, American usury laws are largely ineffective. On the other hand, certain Islamic countries have usury laws that are both effective and intact. Interest in such countries has been abandoned for other 'Islamic' investment modes.

In fact, the practice of regulating interest is ancient; documents dating back thousands of years discuss usury and its impact on society. The most influential documents that addressed the issue of usury and in- 
terest are the religious holy books of Judaism, Christianity, and Islam. Not only is usury mentioned in multiple places in the Torah, the New Testament of the Bible and the Quran, but it is also treated thoroughly throughout these books.

Thus, the aim of this paper is threefold. First, it attempts to collect, explain, and relate all the verses and passages in the holy books of Judaism, Christianity, and Islam that mention usury or interest. Second, it provides recent examples of the impact of interest on the welfare of individuals as well as societies, most notably indebted developing countries. Third, it briefly renders several alternatives for the interestbased finances.

\section{Religions' Stance on Interest (Usury)}

Konow (2012) argues that one of the most dramatic developments in economics over the past few decades has been economists' rapidly increasing willingness to extend their models of human motivation beyond the traditional assumption of narrow self-interest to incorporate moral, ethical and religious values, as well as other social preferences. This paper is interested in the moral and religious dimensions of charging interest, known in the three major religions as usury. Usury is thus defined as any increase in the capital of the lender that occurs solely due to advancing a loan without providing any other service; that is, a loan with the condition that the borrower will return to the lender more than the quantity borrowed solely for the use of the money for a certain period of time. In today's terms, earning interest on a loan would be considered as usury. The religions' position on usury, interest, or debt servicing stands in stark contrast to the current existing structure. Almost all financial institutions engaged in lending money charge interest on their loans, as it is conventionally believed that interest is the price of credit as well as the time period over which the borrower will pay back the loan. The convention in many current financial systems is for debt holders to be saddled with interest rates exceeding $50 \%$ on credit card debt in some European countries, and upwards of $25 \%$ in the US.

Judaism, Christianity and Islam have a very clear stance on the practice of charging interest on financial capital. They all speak against interest and usury in their religious books. Evidence can be found in the holy books of the Talmud (the Oral Torah), the Torah (the five books of Moses, the entire Jewish bible or the Old Testament), the New Testament of the Bible, and the Quran. Interest is mentioned multiple times and in several contexts in all of the holy books. These contexts vary, from setting the rules of borrowing and lending to the description of both positive and negative consequences of the practice of usury.

Reading the texts in different religious holy books, one might immediately be taken by how unlawful practicing interest is considered in the three religions, and also by how stringent the warnings are against any involvement in interest.

In Leviticus 25:37 (King James Version), the text reads:

"Thou Shalt not give him thy money upon usury, nor lend him thy victuals for increase"

In Deuteronomy (23:19), it also reads:

"Do not charge your brother interest, whether on money or food or anything else that may earn interest."

The Talmud references Ezekiel 13 (Hebrew):

"He has lent on usury; he has taken interest; he shall surely not live, having done all these abominations."

Further on, Ezekiel (18:13) refers to the usurer in these terms:

"If he has exacted usury or taken increase -- Shall he then live? He shall not live! If he has done any of these abominations, He shall surely die; His blood shall be upon him ";

This compares the lender on interest to the shedder of blood.

Exodus 22:25 sets certain rules and laws of lending money. The text states,

"If you lend money to any of My people who are poor among you, you shall not be like a moneylender to him; you shall not charge him interest." Another text from Nehemiah (5:10) supports the same concept:

10 "I also, with my brethren and my servants, am lending them money and grain. Please, let us stop this usury!

11 "Restore now to them, even this day, their lands, their vineyards, their olive groves, and their houses, also a hundredth of the money and the grain, the new wine and the oil, that you have charged them." 
On the other hand, Zarabozo (2007) argues that, as is often the case on many practical issues, the New Testament is somewhat vague on the issue of interest. This idea finds support in The Encyclopedia of Religion and Ethics, where it notes that "there are no direct precepts [concerning interest] to guide the Christian conscience." However, this statement does not seem to be accurate. First, Christianity derives its teachings not only from the New Testament but also from the Old Testament. Second, in the New Testament, there are several passages attributed to the teaching of Jesus that are against the practice of charging interest or usury. For example, in Luke (6:35), it reads that Jesus says:

"But, love your enemies, and do good, and lend,

hoping for nothing again; and your reward shall

be great, and ye shall be the children of the

Highest: for he is kind unto the unthankful and

to the evil"

The above verse offers a perspective of how to lend money. Jesus advices his followers not to expect any return from lending money. In fact, this could be interpreted as either not to take any increase on the principal, meaning not to accept or ask for interest, or even to refuse to take back the principal itself.

Verses 14 through 28 in Matthew (25) in the New Testament, which is known as "The Parable of the Bags of Gold", also touch the concept of interest. In fact, the word usury is literally mentioned in Matthew (25:27) in the King James Version, although it is translated as interest in the Standard English version.

"Thou oughtest therefore to have put my mon-

ey to the exchangers, and then at my coming

I should have received mine own with usury [interest]."

Zarabozo (2007) reports the Geneva Study Bible comment on Matthew (25:14-28). It states that usury or loaning money for interest is strictly forbidden by the Bible, even at a rate as low as one per cent. It continues, focusing on the story in Matthew 25, that the servant mentioned in the parable had already told two lies. The first occurred when he said that his master was an austere or harsh man, while the Lord is merciful and gracious. He also called his master a thief because he reaped what he did not sow. The master replied to his servant in Matthew (25:27), when he asks sarcastically, why you did not add insult to injury and loan the money out at interest so that you could also call your master a "usurer"?
One can easily conclude from "The Parable of the Bags of Gold" that charging interest (practicing usury) is among the most serious sins in Christianity; no matter the amount, all interest is unlawful.

Based on the teachings of the Bible, Visser and McIntosh (1998) report [based on Birnie (1958)] that by the fourth century AD, the Roman Catholic Church had prohibited the taking of interest by the clergy, a rule that they extended to the laity in the fifth century. In the eighth century under Charlemagne, they pressed further and declared usury to be a general criminal offence. This anti-usury movement continued to gain momentum during the early Middle Ages and perhaps reached its peak in 1311 when Pope Clement V made the ban on usury absolute and declared all secular legislation in its favor null and void. Many people of that era, however, most notably businessmen who needed to finance their businesses, found this law to be very awkward and created a pragmatic solution to the issue (Sauer, 2003).

Currently, Christian Questions, a popular U.S. Christian talk radio program that aims to provoke discussions along religious lines and provide Christians with answers on debatable issues, argues that "it is obvious from the scriptures that God would not approve of a Christian running a loan shark operation due to the predatory nature of the practice. Because a loan shark lends money for personal gain at excessively high and possibly illegal rates of interest, he takes advantage of a borrower's desperation or inability to borrow money through more legitimate channels, such as banks or mortgage and finance companies. Taking advantage of another's misfortune is contrary to the principles of Christianity set forth by Jesus."

On the other hand, Sauer (2003) reports on Calvin's (1991) perspective on charging interest and its legitimacy. Calvin argues that the scriptural texts implicitly distinguish between fair and unfair interest. The latter of which is condemned by the Bible, has a deleterious impact on the society. This interest is supposedly accompanied by fraud and deception that break the trust and solidarity that bind society together.

The Islamic stance on interest is no different from that of Judaism and Christianity. Indeed, in Islam, the practice of usury is strictly prohibited. In the Quran, the holy book of Islam, multiple verses make explicit refer- 
ences to interest. In the first verse revealed on usury, the text reads (Ar-Rum, 30:39):

"And whatever usury you give so that it may increase

in the wealth of people, it does not increase with God" Like the Bible, the Quran (Albaqara, 2:275-276) lays out the general rules and principles for lenders. The verse also makes a clear distinction between acquiring profit through trade and acquiring profit through charging interest.

"Those who devour usury will not stand except as stands one whom the Satan by his touch has driven to madness. That is because they say, "trade is like usury", but Allah (God) has permitted trade and has forbidden usury"

"Oh you who believe! Fear Allah (God) and give up what remains of your demand for usury if you are indeed believers."

There is clear resemblance between the above verse in the Quran and the passages in Jeremiah (15:10) and Al-Nisaa' (4:161). All of these verses warn the usurer against such practices. The text in Jeremiah reads:

"Woe is me, my mother, That you have borne me, A man of strife and a man of contention to the whole earth! I have neither lent for interest, Nor have men lent to me for interest. Every one of them curses me." Similarly, in Al-Nisaa'(4:161), the Quran states:

"That they took usury though they were forbidden and they devoured peoples wealth wrongfully; we have prepared for those amongst them who reject faith a grievous chastisement."

Consequently, both the Quran and the Bible encourage people to abolish the practice of usury and charging interest through the use of certain incentives. The Bible states in Psalm (15:5):

"He who does not put out his money at usury,

Nor does he take a bribe against the innocent. He who does these things shall never be moved."

Similarly, in Ezekiel (18:17):

"Who has withdrawn his hand from the poor And not received usury or increase, But has executed My judgments And walked in My statutes -- He shall not die for the iniquity of his father; He shall surely live!" In the Quran in Al-Imran (3:130):

"Oh you who believe! Devour not usury doubled and multiplied; but fear Allah (God) that you may prosper."
And in Al-Baqarah (2:276):

"Allah (God) will deprive usury of all blessing, and will give increase for deeds of charity, for he does not love any ungrateful sinner."

The above two sets of verses from the Bible and the Quran reveals God's promises to those who do not practice usury or charge interest. The rewards come in the form of a good, prosperous life as long as he or she lives. On the other hand, the Quran and the Bible are very straightforward about the fates of those who charge interest, as reported in Ezekiel (18:13), "He shall not live! If he has done any of these abominations, He shall surely die", and in the Quran (Al-Baqara, 2:279), " "If you do not [leave usury], take notice of war from Allah [God] and his Messenger"

Not only do the holy books advise people to forbid the practice of usury, but they also encourage them to repent of any past practices. In Al-Baqara (2:279), the Quran explains what the lender shall do if he practiced usury in the past and subsequently decides to give up that practice:

"but if you repent [from practicing usury] you shall have your capital sum. Deal not unjustly and you shall not be dealt with unjustly."

Moreover, the Prophet Muhammed in his famous last sermon on Mount Arafat said:

"All interest obligation shall henceforth be waived. Your capital however is yours to keep. You neither wrong, nor be wronged. God has judged that there be no usury."

Strong support for this Islamic stance is found in the Old Testament in Nehemiah $(5: 10,11)$

"I also, with my brethren and my servants, am lending them money and grain. Please, let us stop this usury!, Restore now to them, even this day, their lands, their vineyards, their olive groves, and their houses, also a hundredth of the money and the grain, the new wine and the oil, that you have charged them."

And in Ezekiel (18:7,8);

"If he has not oppressed anyone, But has restored to the debtor his pledge ---------------- He is just; He shall surely live!"

It is evident that these religions not only prohibit the charging of interest but also encourage the usurers to return all the interest that they had charged earlier because of its status as unlawful profit. Prophet $\mathrm{Mu}$ - 

for silver, wheat in exchange for wheat, barley in exchange for barley, dates in exchange for dates, salt in exchange for salt is in the same category and (should be exchanged) hand to hand, so whoever adds or demands increase he has practiced usury. The giver and taker are the same."

Because Islam does not make a distinction between charging interest to a Muslim or non-Muslim, it also makes it unlawful and forbidden to receive or pay interest. In that regard, the Prophet Muhammed said:

"Allah [God] curses the one who consumes inter-

est, the one who pays it, the one who draws up the contract, and the witnesses to the contract, then he said they are same [in sinfulness]."

This quote (hadith) not only shows that in Islam, it is unlawful not only to receive interest but also to pay it. Both parties share the sin of the transaction of interest. However, there is an extremely important distinction between paying interest and receiving it. This lies in the unlawful wealth that is only acquired by the one who receives interest, as in the Prophet Muhammed's quote:

"One whose flesh has grown out of unlawful

food, the fire is more suitable for him."

In fact, the one who pays the interest is not left with unlawful wealth as a consequence of it. Therefore, we cannot say that the one who pays interest is sinning on the same terms as the lender, simply because the Prophet Muhammed's teachings on paying or receiving interest may refer to the cumulative sins that come from consuming unlawful wealth, which only apply to those who consume (earn) interest, not to those who pay it.

\section{Flaws in Interest-Based Finances}

The basis behind the unlawfulness of interest in religion stems from the role and function of money in society. While today, money is treated as a commodity, Islam, for instance, treats money as only a medium of exchange and store of value because money cannot perform any function unless it is exchanged for any real asset. That is, money has no intrinsic value or utility. As a result, not only is charging interest on a loan unlawful in Islam but also any exchange of any other commodity for unequal quantity on a deferred payment basis if the commodities are the same.

Bleher (2009) presents an important idea where he argues that while the practice of charging interest is forbidden by Judaism, Christianity and Islam alike, it has become universally accepted in the modern secular world. Thus, he disagrees with the current belief that money is a "producer good" and that the lender should receive a share of the extra wealth that these goods produce. He argues that the only true producer of wealth (i.e., goods and services) is labor when it is applied to either land or capital. Unlike land, money is infinite when it is not artificially restricted, as it often is. Money is man-made from nothing at a miniscule real cost. The creation of credit confers enormous economic power and influence on those usually private institutions who have secured for themselves monopoly rights over the creation of money. Thus, when banks create money, they lend what they do not have and they later collect interest. In most cases, bank loans are not backed by any real wealth, except for the fact that the government, with the central bank as lender of the last resort, is ready to bail out the banks should a run on their money occur. In this regard, one of the world's most prominent central bankers, Lord Josiah Stamp, director of the Bank of England from 1928 to 1932, stated that

"The modern banking system manufactures money out of nothing. The process is perhaps the most outstanding piece of sleight of hand that was ever invented...If you want to be slave to the bankers, and pay the costs of your own slavery, then let the banks create money."

Consequently, the money that one owns is only worth the paper on which it is printed and is only deemed to have purchasing power value because people have confidence in the economic system. If any serious threat confronts an economy, the value of its money decreases significantly, and in certain cases, that money is no longer accepted as means of exchange. This phenomenon occurred in Latin America in 1997, known as the "Tequila Effect", and was seen globally in the 2007-2008 financial crises. The financial institutions responsible for money creation gained excessive power and control over the economy, and their abuse of this power led to a disastrous outcome. Money creation is ultimately a deceptive system that allows an expansion in the supply of paper money without a corresponding rise in the assets held by the bank. This new money is thus only available to society through taking an interest bearing loan from the bank. Early American president Thomas Jefferson stated, 
"If the American people ever allow the banks to control the issuance of their currency, first by inflation then by deflation, the banks and corporations that will grow up around them will deprive the people of all property until their children will wake up homeless on the continent their fathers occupied. The issuing power of money should be taken from the banks and restored to Congress and the people to whom it belongs. I sincerely believe that banking institutions are more dangerous than standing armies."

LaCour-Little, Calhoun and Yu (2011) examine Jefferson's quote by investigating the role of piggyback lending, a form of simultaneous close junior lien lending that emerged to take advantage of the high profits of money creation in the collapse of the mortgage market. They find that piggyback lending is among the causes of the 2007-2008 financial turmoil, and their results suggest that that the fraction of piggyback originations is related to higher foreclosure and defaults in subsequent years, which was the primary reason for bank runs in the U.S. beginning in 2008.

The defaults and foreclosures that hit the U.S. housing market have caused volatility in housing prices, which has caused subsequent defaults and foreclosures. Archer and Smith (2013) note that housing price volatility has caused both lenders and borrowers to alter their perceptions of price trends. After the collapse of the housing market, high mortgage rates compared to the current prices of houses caused many borrowers to voluntarily default on their mortgage payment as housing prices significantly depreciated. Sanders (2008) supports the above argument. He claims that subprime mortgage defaults were primarily triggered by the significant decline in housing prices.

On the other hand, money creation, lending, interest, and debt have created the biggest redistribution of income in favor of the rich in history. Shahjahan (2000) notes the impact of debt and the burden of interest on the American middle class, where debt has caused many farmers to pawn their farms and, in certain cases, to lose these farms due to high (compounded) interest payments. He claims that $15 \%$ of the annual income of middle class households goes to interest payments, and states that the average size of these families' debts during the four year period from
1990 to 1993 was $\$ 32,500$, which is equivalent to almost $100 \%$ of these families annual income.

On the other hand, access to investment loans has been made very easy--not for those with the most feasible projects, but for those with the most collateral, who by definition are the wealthiest in society. By giving the rich cheap and easy access to money, the interest rate mechanism has a tendency to favor the rich and discriminate against the poor. In this regard, interest-based banking inhibits economic growth by failing to finance the most feasible business ideas that, if supported, would have resulted in higher economic growth.

Furthermore, interest can also be a source of market imperfections. This occurs when lenders limit the supply of additional credit to borrowers who demand funds, even if the latter are willing to pay higher interest rates. In this case the price mechanism, which is interest rates, fails to bring equilibrium to the market. In this regard, Stiglitz and Weiss (1981) developed a model to show that the borrower would be willing to obtain the funds at a higher interest rate than that charged by the lender, but that the lender would not be willing to lend the extra funds because the higher rate would imply lower expected profits. This is equilibrium rationing, as there is excess demand for credit at the equilibrium rate of interest due to adverse selection, the situation in which the lender is faced with borrowers whose projects imply different levels (or types) of risk, and the type of each borrower is unbeknownst to the lender. The main intuition behind this result is that safe borrowers would not be willing to tolerate a high interest rate because with a low probability of default, they will end up paying back more to the lender. Risky types will accept a higher rate because they have a lower chance of a successful project (and typically a higher return if successful), and thus a lower chance of repayment.

The impact of interest rates and debt on countries, especially developing countries, is more devastating and dangerous than for individuals. Although most less developed countries have borrowed from international commercial banks, i.e., the IMF or the World Bank, several studies argue that these loans failed to improve the quality of life in those countries. In fact, in many developing countries, interest payments (debt service) constitute a greater percentage of GDP 
than education, healthcare, and infrastructure combined (Hertz, 2009). Hertz (2009) argues that much of the debt in developing countries was incurred at a time when commercial banks needed to make loans. Jesse Jackson, an American civil rights leader, stated that "They no longer use bullets and ropes; they use the World Bank and the IMF". It is a fact that no country has ever paid off a debt to the World Bank or private banks. Usmani (2005) reports that during the period from 1982 to 1990 , developing countries paid $\$ 1.9$ billion in interest and capital to creditor countries. He argues that the loans forwarded to many developing countries are not linked to specific developmental projects and therefore constitute pure interest-bearing debt, secured against what natural resources these countries may have. Populations have suffered as their mineral wealth has been used to service interest-based debt instead of being used to provide essential services. Perkins (2004) notes the power that the lender has over the borrower (developing countries). Lender banks and institutions usually offer advice or dictate conditions for how countries manage their finances and conduct themselves in the international markets. He writes, "They [loans] were intended to create large profits for the contractors, and to make a handful of wealthy and influential families in the receiving countries very happy, while assuring the long run financial dependence and therefore the political loyalty of governments "The larger the loan, the better." The fact that the debt burden placed on a country would deprive its poorest citizens of health, education, and other social services for decades to come was not taken into consideration."

Moreover, financial distortion, which usually occurs in interest rate finance regimes, is a major impediment to economic growth. Guarigila and Poncet (2008) argue that although indicators measuring the degree of market-driven financing in the economy are positively associated with growth, these effects have been gradually declining over time as countries have become more involved in the global economy.

\section{Alternatives to the Conventional Interest-Based Finance}

As mentioned earlier, interest should not be considered as a payment for a factor of production; even if this is true, interest still has several unique characteris- tics that distinguish it from other payments of factors of productions, which eventually lead to many undesirable outcomes. As a result, there have been efforts to establish interest-free financial institutions in order to prevent borrowers from being exploited by lenders. Muslim-majority countries have been the leaders in providing these types of services. These countries combined have hundreds of interest-free institutions known as Islamic banks. Moreover, Islamic financial institutions also exist in the U.S. and several western European countries, i.e., the Devon Bank in the U.S., the Islamic Bank of Britain in the U.K., and Kuveyt Turk Bank in Germany. Other faith groups, such as Jews and Christians, have followed the Muslim lead and established interest-free lending institutions. Although these institutions are not as popular and widespread as Islamic banks, they are nevertheless a step towards the new vision of non-interest based banking. In New York City, the first non-Muslim attempt at an interest-free institution was made by the Hebrew Free Loan Society, which works under the umbrella of the International Association of Jewish Free Loans. These societies are found in different states in the U.S., Canada, Australia, and Jerusalem. Another successful attempt to apply free interest loan concept has been made by the Swedish bank JAK Medlemsbank, which has branches in Denmark and Ireland.

The abovementioned argument for zero interest will not lead people to seek to abolish the mechanism through which funds are allocated. In fact, zero-interest financing is based on a joint venture between the borrower and the lender. If the borrower needs to borrow the money for investment (not consumption) reasons and the lender needs to increase his capital through borrowing, then both should share the risk. This joint venture, or 'Musharakah in islam", is a relationship established under contract by the mutual consent of the parties for sharing profits and losses in the joint business. It is an arrangement under which the bank provides funds, at which it time cannot guarantee itself a fixed return. This mechanism is highly beneficial as the bank becomes concerned about the results of its investment. In this regard, lender banks are automatically encouraged to identify and select the ventures with the greatest potential for profit, rather than relying on those that offer the greatest collateral.

This new system of profit sharing rather than inter- 
est charging will deprive private banks and financial elites from their extraordinary power, which will render them unable to manipulate the economic cycle, thus avoiding events such as the Great Depression of the 1930s and the 2008 Financial Crisis. Economic power is thus retained by the government, which ensures that all paper currency is fully asset-backed.

In conclusion, profit is more efficient than interest as a mechanism to allocate loanable funds.

\section{Conclusion}

This paper investigates the stance of Judaism, Christianity, and Islam on interest. The passages and verses in the Torah, the Bible, and the Quran make evident that the practice of earning interest through advancing loans is strictly prohibited in the three major monotheistic religions. It is believed that this practice exploits, extorts, and takes advantage of the borrower.

In fact, weighing the flaws and disadvantages of charging interest against its benefits and advantages, this paper finds that the flaws outweigh the benefits for several reasons. First, high interest rates depress investment opportunities that have low profits relative to interest charged in the short run, regardless of their importance to society in terms of their output and the number of workers employed. The feasibility of the project is known not to be the primary determinant of being approved for a loan. Second, interest rate finances lead to credit (money) creation, which confers tremendous economic power on financial institutions. These financial institutions gain power over the economy and any misuse of this power can lead to disastrous outcomes such as the Great Depression and the 20072008 global financial crises. Third, interest has a strong negative impact on social harmony. Because the major portion of wealth in each society is captured by a very few, the rest of society is left saddled with large debts and high interest rates, bringing to mind the popular saying, "The rich get richer and the poor get poorer." This can be witnessed in many countries where people pawn their homes, farms, and other precious belongings, which they may later lose to their lenders. This causes the division of society into two antagonistic classes, which leads to an ominous class struggle, jealousy, a sense of unfairness, and murder. Fourth, interest places a huge burden on many indebted developing countries. Debt service in several countries exceeds spending on basic services, such as education, healthcare, and infrastructure. Furthermore, international financial institutions, such as the World Bank and IMF, have forwarded loans to countries with corrupt regimes that are not linked to any developmental projects, thereby passing off the burden of paying back the loan to the next generation.

As a result, several interest-free financial institutions have started to appear all over the world. Islamic financial institutions have taken the leading role, and have been followed by some Jewish and Christian institutions. However, the free interest concept should not be misunderstood as abolishing the capital allocation mechanism. In fact, the new interest-free system should be based on another mechanism that avoids the flaws of the old system. The paper briefly reviewed "Profit" as the new mechanism to replace interest. Indeed, future research is needed to study other alternatives to the current system in depth.

\section{References}

Al-Quran.

The Bible, King James version.

The Bible, Standard English version.

Archer, W. \& Smith, B. (2013). Residential mortgage defaults: the roles of house price volatility, euphoria, and the borrower's put option, The Journal of Real Estate Finance and Economics, 46 (2), 355378.

Birnie, A. (1958). The History and Ethics of Interest. London, UK: William Hodge \& Co.

Bleher, S. (2009). The Fact about Usury: Why Islam is against lending money at interest (Unpublished article). Retrieved from http://www.mustaqim. co.uk/usury

Calvin, J. (1991). Calvin's Ecclesiastical Advice (M. Beaty and B. Farley, Trans.). Louisville, KY: Westminster John Knox Press.

Guariglia, A, \& Poncet, S. (2008). Could financial distortions be no impediment to economic growth after all? Evidence from china. Journal of Comparative Economics, 36 (4), 633-657

Hertz, N. (2009). The Debt Threat: The Story of the Third World Debt, New York, NY: HarperCollins Inc. 
Konow, J. (2012). Adam Smith and the Modern Science of Ethics. Economics and Philosophy, 28 (3), 333-362.

LaCour-Little, M., Calhoun, C. A., \& Yu, W. (2011). What role did Piggyback lending play in housing bubble and mortgage collapse? Journal of Housing Economics, 20 (2), 81-100.

Perkins, J. (2004). Confessions of an Economic Hit Man. San Francisco, CA: Berrett-Koehler Inc.

Sanders, A. (2008). The subprime crisis and its role in the financial crisis. Journal of Housing Economics, 17 (4), 254-261.

Sauer, J. (2003). Christian Faith, Economy, and Economics: What Do Christian Ethics Contribute to Understanding Economics. Faith and Economics, 42, 17-25.

Shahjahan, M. (2000). Debt and the Quest for Rich America: The Economic Tale of Small and MidSized US Cities. Beltsville, MD: Writers' Inc. International.

Stiglitz, J., \& Weiss, A. (1981). Credit Rationing in Markets with Imperfect Information, The American Economic Review, 71 (3), 393-410.

Usmani, M. (2005). Why Islam has Prohibited Interest, First Ethical, Bolton, UK: Chorley House.

Visser, W., \& Mcintosh, L. (1998). A Short Review of the Historical Critique of Usury. Accounting, Business, and Financial History, 8 (2), 175-189.

Zarabozo, J. (2007). What is Islam? Riyadh: Ministy of Islamic Affairs, Saudi Arabia. 